$\begin{array}{r}\text { Volume and Issues Obtainable at Center for Sustainability Research and Consultancy } \\ \text { Journal of Accounting and Finance in Emerging Economies } \\ \text { ISSN: 2519-0318 ISSN (E) 2518-8488 } \\ \text { Volume 3: Issue 2 December 2017 } \\ \text { JSRᄃ } \\ \text { Journal homepage: } \text { www.publishing.globalcsrc.org/jafee } \\ \hline\end{array}$

\title{
An Alternative Explanation for Stock Price Increases among the S\&P 500 following a Stock Buyback Announcement
}

\author{
${ }^{1}$ Jose E Munoz \\ ${ }^{1}$ Point Loma Nazarene University,San Diego, California, United States, JoseMunoz@ pointloma.edu
}

\begin{tabular}{l}
\hline ARTICLEDETAILS \\
\hline History \\
Revised format: Nov 2017 \\
Available online: Dec 2017
\end{tabular}

\section{Keywords}

Stock Buybacks,

Repurchases,

Signaling, S\&P 500,

Abnormal Returns

JEL Classification:

$R 53$

\begin{abstract}
Purpose:The purpose of this paper is to investigate an alternative, more basic explanation for stock price increases among the Standard \& Poor's 500 Index following a stock buyback announcement than the signaling theory offered in current literature.

Methodology: Three related sets of data were collected and analyzed for 1,858 individual S\&P 500 stock buyback announcements occurring during the period 2005-2015: First, the actual stock prices for 6 different times from the buyback announcement date $(t)$ to one year after $(t+365)$; second, the S\&P 500 Index for the same dates; and third, the mathematical price of the stock resulting from the reduction in buyback shares.

Results: The results demonstrate that the greatest contributor to the postbuyback-announcement share price increase is due to the combination of general market moves (S\&P 500 Index) and the mathematical reduction in shares occurring from the buyback. No support is found for the signaling theory.

Implication: This researchpresents a conceptually yet empirically supported framework to describe the significance of the mathematical reduction in shares as a contributing factor in the post-buyback-announcement share price increase as compared to alternatives offered in the current literature. This paper is particularly useful for those who study stock market behavior and the causes of the share price increase that follow a stock buyback announcement.
\end{abstract}

(C) 2017 The authors, under a Creative Commons AttributionNonCommercial 4.0

Corresponding author's email address: JoseMunoz@ pointloma.edu

Recommended citation:Manoz, J., (2017).An Alternative Explanation for Stock Price Increases Among the S\&P 500 Following a Stock Buyback Announcement. Journal of Accounting and Finance in Emerging Economies, 3(2)

137-146.DOI:https://doi.org/10.26710/jafee.v3i2.92

\section{Introduction}

The purpose of this paper is to investigate an alternative, more basic explanation for stock price increases among the Standard \& Poor's 500 Index following a stock buyback announcement than the signaling theory offered in current literature. The paper also has a secondary objective of determining support for the existence of abnormal returns reported in earlier literature concerning the stock price performance of buyback stocks after the buyback is announced.

This paper reports the findings of an extensive study of the 1,858 open market stock buybacks announced by member firms of the Standard \& Poor's 500 Index (S\&P 500) during the period 2005-2015. 
Prior to an examination of the current literature concerning abnormal returns and the signaling theory, it is necessary to set the stage for the importance and growth of stock buybacks.

\subsection{Stock Buybacks (Share Repurchases) - History \& Significance}

It is necessary to review the history and growth of stock repurchases, or buybacks, in order to understand their significance in the world of corporate finance and dividend policy. Until at least 1982, cash dividends were the only major form of cash distribution available to shareholders. Share repurchases or stock buybacks were seldom utilized for a variety of reasons, mainly involving ethical and legal issues concerning perceived stock price manipulation by those firms engaging in share repurchases (Lightner, et al., 2008). Until 1982, there existed a legal arena of 'significant disincentive' for a firm to engage in the repurchase of its own shares (Ross, 2011, p. 513).

Then in 1982, the SEC Rule 10b-18, was issued by the SEC, which finally established a clear set of guidelines for the repurchase of shares (Grullon, 2002). This was enacted after years of debate (Ross, 2011).

As a result, and instead of paying a cash dividend to shareholders, a company could choose to use cash to buy back, or repurchase, shares of its own stock. Repurchases and cash dividends have a similar effect of getting cash into the hands of shareholders, while at the same time reducing the number of shares outstanding, and mathematically increasing the share price (Ross, 2011). Lease, et. al., (2000) note that the U.S. is one of the few countries in the world that offers its corporations the ability to buy back its own shares.

Many writers have documented the tremendous growth in open market stock repurchases and note the explosion that occurred in the 1990's, when for the first time, repurchases surpassed cash dividends in total payments in 1997, including Grullon (2000), Chetty (2005), Fama (2001), Grullon (2002), Hsieh (2008), Russolillo (2016), and Zeng (2016). In only one of those years since 1997 did dividends exceed repurchases, and that was in the recession year of 2009. Table 1 and Figure 1 show the data for stock buybacks and cash dividends for the period, 2007-2015.

Table 1. Dividends and Buyback Amounts for S\&P 500 Index Member Firms 2007-2015

(In \$millions)

\begin{tabular}{|c|c|c|}
\hline Year & Dividends & Buybacks \\
\hline 2007 & $\$ 247$ & $\$ 589$ \\
\hline 2008 & $\$ 247$ & $\$ 340$ \\
\hline 2009 & $\$ 196$ & $\$ 138$ \\
\hline 2010 & $\$ 205$ & $\$ 300$ \\
\hline 2011 & $\$ 240$ & $\$ 405$ \\
\hline 2012 & $\$ 280$ & $\$ 400$ \\
\hline 2013 & $\$ 312$ & $\$ 475$ \\
\hline 2014 & $\$ 351$ & $\$ 553$ \\
\hline 2015 & $\$ 383$ & $\$ 572$ \\
\hline
\end{tabular}

Source: S\&P Dow Jones Indices, various years, most recent data: http://us.spindices.com/search/?query=buybacks+and+dividends\&Search=GO\&Search=GO 


\section{Figure 1}

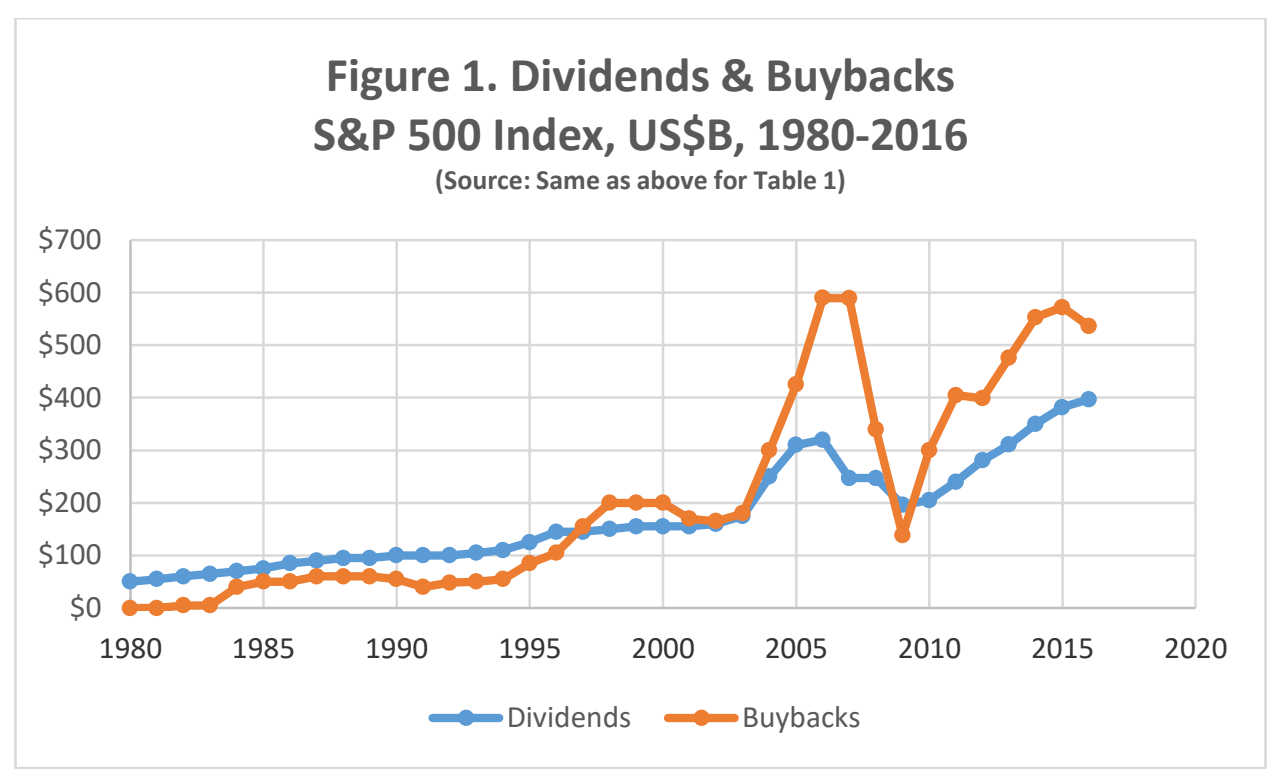

\subsection{Abnormal Returns \& Buyback Announcements}

Abnormal returns are those returns above normal market returns that can be earned by an investor due to the inefficiency of the markets and irrationality of investor behavior as it relates to the availability of information to all investors. A normal return is defined as that rate generally available to all investors in the market, or the market rate of return (Baker, 2009, and Ross, 2011).

The US markets are generally assumed to be efficient, which is based on the premise that varying degrees of information about a firm are known to all investors, and are reflected in the price per share of the stock, and which is based on rational investor behavior. Because of this, no one earns consistently abnormal, or superior, returns in the market (Ross, 2011). Therefore, firms that announce stock buybacks should not yield abnormal returns in share price.

However, several researchers challenge those assumptions when it relates to stock repurchase announcements. In other words, an abnormal rate of return is a rate of return that beats the market and is above normal market returns that can be earned by the investor, due to the inefficiency of the markets combined with irrational investor behavior as it relates to repurchase announcements (Baker, 2009). Investors are able to beat the market's normal returns, and can earn abnormal returns with respect to buyback stocks. If the markets were efficient, share prices would adjust immediately and there would be no avenue to beat the market (Brav, 2005).

Several studies report abnormal returns for firms that announce share repurchase programs. Above market (abnormal) returns are reported for periods of time from thirty days before and after the announcement date for fixed-price tender offers (Lakonishok, 1990). Another study finds similar abnormal returns for periods of sixty days before and after the announcement date (Peyer, 2005). Still another study finds abnormal returns for one and twelve month horizons for repurchasing companies (Ikenberry, 1995).

More recently, in January 2014, another study conducted during the period January 2004-July 2013, comes to the following conclusions: (a) Buyback announcements result in excess returns of $0.60 \%$ for one month and $1.38 \%$ for one year after announcement dates compared to the Russell 3000 Index, and (b) Excess return performance is greatest with larger buybacks (as measured in percent of shares outstanding) (Fruin, 2014). 
Put another way, Fruin (2014) states that "US firms that authorize and announce share repurchase programs, aka buybacks, have historically shown statistically and economically significant out performance following the announcement, and according to our research, this trend has continued over the past nine years", and "in larger capitalization stocks, market response to repurchase announcements has been much faster" (p. 15).

The S\&P 500 Buyback Index follows the ' 100 companies in the S\&P 500 with the highest buyback ratio in the trailing 12-month period' (Zeng, 2016, p. 8). Zeng's study in April 2016 documents that 'over the 20-year period ending Dec. 31, 2015, the S\&P 500 Buyback Index outperformed the S\&P 500 in 16 out of 20 years' (p.8).

All of these studies clearly build strong support for the ability to obtain abnormal returns for the share prices of firms that announce buybacks.

\subsection{Signaling Theory}

Multiple reasons or motives have been presented for a firm initiating stock buyback programs. Baker (2002) lists the following: signaling, tax rate differentials, agency, capital market allocations, cash flow availability, and a source of shares for executive/employee stock options. Peyer (2009) adds several more, including, undervaluation of stock price, best use of cash, means of getting cash to shareholders, dilution avoidance due to stock options, earnings per share (EPS) strengthening, capital restructuring, and others. Grullon (2004) believes the buyback announcement is another form of signaling, in this case, a reduction in overall firm risk.

The basic signaling theory holds that a stock repurchase announcement indicates a signal from the board of directors and executive management that the firm's future fortunes (and earnings) are about to improve, which is why the firm is buying back its stock at share prices which are likely to improve in the future (Ikenberry, 1995). This is supportive of the asymmetric information reasoning, in that one party (board of directors and executive management), has better, more relevant, and more accurate information than the other party (shareholders) (DeAngelo, 2008). Therefore, the reasoning flows, if executive management is buying the firm's stock, then shareholders should follow suit. These researchers ascribe the abnormal risks to the signaling theory.

\subsection{Impact on Share Price Resulting from Reduced Number of Shares after a Buyback}

This is a mathematical exercise resulting from a share repurchase program which causes a reduction in the number of shares outstanding, without changing anything else related to earnings. In other words, it impacts purely on the denominator of the EPS formula, which is briefly described as net income minus preferred dividends (numerator) divided by number of shares outstanding (denominator) (Ross, 2011).

Since the denominator shrinks by the amount of the repurchase program, the resulting EPS must rise due solely to the mathematics involved (Ross, 2011). An example to illustrate the impact of a share repurchase program is presented below in Table 2 .

Please note that the P/E ratio was held constant at 20.0 in the table below. This is consistent with Ross (2011), who states that the P/E ratio should stay the same, since both the business and financial risks of the firm are unchanged between a repurchase and a dividend, and before and after a repurchase.

Also, two scenarios are presented below. One is at a $100 \%$ buyback of the share repurchase announced, 
and the other is at an $80 \%$ buyback of the share repurchase announced. This is in keeping with the research by Russolillo (2016), Brigham (2014), Ross (2011), and Stephens (1998). They concluded that only about $80 \%$ of the announced shares to be repurchased are actually repurchased, usually at the end of one year from the announcement date.

\section{Table 2. How Buybacks Raise Share Prices Due Solely to the Reduction in Shares Outstanding Under Two Scenarios: 100\% Buyback and $89 \%$ Buyback}

\begin{tabular}{|c|c|c|c|}
\hline & & $\begin{array}{c}\text { At 100\% } \\
\text { Buyback: }\end{array}$ & $\begin{array}{c}\text { At 80\% } \\
\text { Buyback: }\end{array}$ \\
\hline Pre Repurchase: & Pre Repurchase Share price: & $\$ 80.00$ & $\$ 80.00$ \\
\hline & P/E ratio: & 20.0 & 20.0 \\
\hline & EPS: & $\$ 4.00$ & $\$ 4.00$ \\
\hline & Shares Outstanding: & $\$ 100$ million & 100 million \\
\hline & Total net income: & $\mathbf{5}$ million & $\mathbf{4}$ million \\
\hline Repurchase: & Shares re-purchased, in shares: & $\mathbf{5 . 0 0 \%}$ & $\mathbf{4 . 0 0 \%}$ \\
\hline & Shares re-purchased, in \%: & $\mathbf{9 5}$ million & $\mathbf{9 6}$ million \\
\hline & Shares outstanding: & $\$ 400$ million & $\$ 400$ million \\
\hline & Total net income (unchanged): & $\mathbf{\$ 4 . 2 1}$ & $\mathbf{\$ 4 . 1 7}$ \\
\hline & New EPS: & 20.0 & 20.0 \\
\hline & P/E ratio (unchanged): & $\mathbf{\$ 8 4 . 2 0}$ & $\mathbf{\$ 8 3 . 4 0}$ \\
\hline & New share price: & $\mathbf{5 . 2 5 \%}$ & $\mathbf{4 . 2 5 \%}$ \\
\hline
\end{tabular}

Shaded numbers in bold are highlighted to show differences between $100 \%$ buyback and $80 \%$ buyback. Source: Adapted from Ross (2011), Stephens (1998) and Brigham (2014).

\section{Limitations of Study}

There are several limitations to this research. First, this paper studied only open-market stock buybacks, since Lightner found that greater than $90 \%$ of all stock repurchases use the open-market method (2008). Second, this paper excluded those stock buybacks for which there was no formal buyback announcement found in a company's official press releases. Every one of the 1,858 open market stock repurchases studied in this paper were traced to an official buyback announcement. There are a few companies that initiate buybacks without a formal announcement, or that only make an initial buyback announcement. Only those buyback announcements that could be traced to an official press release were included in this study.

Third, this study is limited to only the member firms of the S\&P 500 Index, which is a widely followed broad-based market index that "tracks the total market value of 500 of the largest U.S. corporations (Ross et al., 2011, p. 311). Fourth, this study includes only the period 2005-2015, which although it includes flat, falling, and rising markets, may not be indicative of performance of stocks and markets prior to 2005, and subsequent to 2015. Fifth, only US-based firms were considered in this study to avoid any differences and complexities of international laws and regulations concerning corporate governance, investment, share repurchases, and taxation.

\section{Methodology}

Three related sets of data were collected and analyzed for 1,858 individual S\&P 500 stock buyback announcements occurring during the period 2005-2015: First, the actual stock prices for six different times from the buyback announcement date $(\mathrm{t})$ to one year after $(t+365)$; second, the $\mathrm{S} \& \mathrm{P} 500$ Index for the same dates; and third, the mathematical price of the stock resulting from the reduction in buyback shares. This dataset comprises all announced stock buybacks by S\&P 500 member firms for the period.

The time periods selected for study were consistent with prior research and were as follows: $t$ (announcement date), $t+1, t+5, t+30, t+60, t+365$. The data for these six time periods was then compared to the stock prices and S\&P 500 Index for $\mathrm{t}-1$, the day before the buyback announcement. 
The data collected in the first two steps outlined in the previous paragraph permitted this researcher to observe the occurrence of abnormal (above market) returns by comparing the actual stock price to the market index (S\&P 500 Index) for each of those six time periods.

This, however, was not the main purpose of the study. Based on the literature, the author prepared a model of expected behavior to test for any signaling theory effects on the increase in stock price. The model tested was embodied in the following formula for each of the six time periods tested ( $t$ through $\mathrm{t}+365$ ) compared to $\mathrm{t}-1$ :

$\Delta I+\Delta M+\Delta S=\Delta P_{\text {through } t+365}$

Where: $\quad I=$ Change in the market index (S\&P 500 Index)

$\mathrm{M}=$ Mathematical price change due to buyback (at 2 levels, $80 \%$ buyback, and $100 \%$ buyback)

$\mathrm{S}=$ Change in stock price due to the signaling theory

$\mathrm{P}=$ Total change in stock price

The model would be tested at each of the six time periods at two buyback levels, the theoretical $100 \%$ of announced shares, and the practical $80 \%$ of historical buyback acquisition, for a total of twelve different tests. The model was based on the premise that the stock price would move with the market (normal returns), plus would move again just as a function of the math of the reduced number of shares, and then finally, would move again due to the positive effects of the signaling theory. The expectation was that all three, $I, M$, and $S$, would be positive numbers in an upward market, or that $I$ would be negative in a down market with $M$ and $S$ positive ( $M$ due to the math, and $S$ due to the definition of the signaling theory. This researcher believes the first two numbers must be excluded from a calculation of signaling theory effects to avoid crediting stock price changes to market and math forces not related to the signaling theory.

\section{Results}

\section{a. Abnormal Returns}

Table 3 below presents the findings as to the existence of abnormal returns for member stocks of the S\&P 500 Index who announced buybacks during the period 2005-2015.

Table 3. Calculation of Abnormal Returns, 2005-2015

\begin{tabular}{|l|l|l|l|}
\hline Time Period & $\begin{array}{l}\text { Mean Actual } \\
\text { Stock Price \% } \\
\text { Change }\end{array}$ & $\begin{array}{l}\text { Mean Actual S\&P } \\
\text { 500 Stock Index \% } \\
\text { Change }\end{array}$ & $\begin{array}{l}\text { Abnormal Returns } \\
\text { (= Stock Price - } \\
\text { S\&P 500 Index })\end{array}$ \\
\hline $\mathrm{t}$ & $+0.516 \%$ & $+0.008 \%$ & $+0.508 \%$ \\
\hline $\mathrm{t}+1$ & $+1.126 \%$ & $+0.032 \%$ & $+1.094 \%$ \\
\hline $\mathrm{t}+5$ & $+1.347 \%$ & $+0.170 \%$ & $+1.177 \%$ \\
\hline $\mathrm{t}+30$ & $+2.155 \%$ & $+0.682 \%$ & $+1.473 \%$ \\
\hline $\mathrm{t}+60$ & $+2.895 \%$ & $+1.280 \%$ & $+1.615 \%$ \\
\hline $\mathrm{t}+365$ & $+11.036 \%$ & $+5.559 \%$ & $+5.477 \%$ \\
\hline
\end{tabular}

The data and results of this research support the prior studies that have consistently found the existence of abnormal returns for companies that announce stock buybacks. Mean stock prices moved $0.516 \%$ between the day before the buyback announcement $(\mathrm{t}-1)$ and the announcement date, $(\mathrm{t})$, while the market 
was almost unchanged, for an abnormal return of $0.508 \%$ for the 1,858 buyback events. This grew consistently for each of the next four time periods, which culminated at $\mathrm{t}+365$, when the stock price moved up $11.036 \%$, compared to a market move of $5.559 \%$, which yielded an abnormal return of $5.477 \%$.

\section{b. Existence of the Signaling Theory}

This study examined buybacks at two levels: a theoretical buyback of $100 \%$ of the announced shares, and a more historical buyback of $80 \%$ of the announced shares, in keeping with prior studies cited earlier in this paper. The results will be presented for each buyback level, and discussed separately.

\section{i. Theoretical Buyback of $\mathbf{1 0 0 \%}$ of the Announced Shares}

Table 4 below presents the results related to the theoretical buyback of $100 \%$ of the announced shares at each of the six time periods ( $t$ through $t+365)$.

Table 4. Results of Calculations for Signaling Theory Effects at the Theoretical $100 \%$ of Announced Shares

\begin{tabular}{|l|l|l|l|l|l|}
\hline & $M$ & $I$ & $M+I$ & $P$ & $S$ \\
\hline & $\begin{array}{l}\text { Math Price \% } \\
\text { Change at 100\% } \\
\text { Buyback }\end{array}$ & $\begin{array}{l}\text { Mean Actual S\&P } \\
\text { 500 Stock Index } \\
\text { Change }\end{array}$ & $\begin{array}{l}\text { Subtotal: Math } \\
\text { Market }\end{array}$ & $\begin{array}{l}\text { Mean Actual } \\
\text { Stock Price \% } \\
\text { Change }\end{array}$ & $\begin{array}{l}\text { Amount } \\
\text { Remaining Due to } \\
\text { Signaling }\end{array}$ \\
\hline $\mathrm{T}$ & $+7.661 \%$ & $+0.008 \%$ & $+7.669 \%$ & $+0.516 \%$ & $-7.153 \%$ \\
\hline $\mathrm{t}+1$ & $+7.661 \%$ & $+0.032 \%$ & $+7.693 \%$ & $+1.126 \%$ & $-6.567 \%$ \\
\hline $\mathrm{t}+5$ & $+7.661 \%$ & $+0.170 \%$ & $+7.831 \%$ & $+1.347 \%$ & $-6.484 \%$ \\
\hline $\mathrm{t}+30$ & $+7.661 \%$ & $+0.682 \%$ & $+8.343 \%$ & $+2.155 \%$ & $-6.188 \%$ \\
\hline $\mathrm{t}+60$ & $+7.661 \%$ & $+1.280 \%$ & $+8.941 \%$ & $+2.895 \%$ & $-6.046 \%$ \\
\hline $\mathrm{t}+365$ & $+7.661 \%$ & $+5.559 \%$ & $+13.220 \%$ & $+11.036 \%$ & $-2.184 \%$ \\
\hline
\end{tabular}

For each time period, the data provided unexpected results from those depicted by the formula in the Methodology section. The data produced a negative amount for the signaling theory in every one of the six periods. In other words, the sum of $M$ (math change due to share reductions) and $I$ (market index) that was greater than $P$ the actual stock price change), instead of less than $P$. Had the sum of $M+I<P, S$ (signaling theory) would have been positive, lending support to the existence of a stock price increase due to the signaling theory.

However, the opposite occurred in each of the six periods, and $M+I>P$, which produced a negative number for $S$, ranging from $-2.184 \%$ at $\mathrm{t}+365$ down to $-7.153 \%$ at $\mathrm{t}$. The results were more negative for $S$ the closer the date was to $t$. The farther away from $t$, the lesser was the negative number. But, the values for $S$ were always negative.

A comparison of each formula is presented below:

Expected results: $\Delta I+\Delta M+\Delta S=\Delta P_{t \text { through } t+365}$

Actual results: $\Delta I+\Delta M-\Delta S=\Delta P_{t \text { through } t+365}$

\section{ii. Historical Buyback of $80 \%$ of the Announced Shares}

As one might have expected, the results at the $80 \%$ buyback level were similar to those at the $100 \%$ buyback level, only smaller in size for each of the six time periods, which can be explained by the math 
involved. The results at the $80 \%$ buyback level are presented below in Table 5 .

Table 5. Results of Calculations for Signaling Theory Effects at the Historical $80 \%$ of Announced Shares

\begin{tabular}{|l|l|l|l|l|l|}
\hline & $M$ & $I$ & $M+I$ & $P$ & $S$ \\
\hline & $\begin{array}{l}\text { Math Price \% } \\
\text { Change at 100\% } \\
\text { Buyback }\end{array}$ & $\begin{array}{l}\text { Mean Actual S\&P } \\
\text { 500 Stock Index } \\
\text { Change }\end{array}$ & $\begin{array}{l}\text { Subtotal: Math } \\
\text { Market }\end{array}$ & $\begin{array}{l}\text { Mean Actual } \\
\text { Stock Price \% } \\
\text { Change }\end{array}$ & $\begin{array}{l}\text { Amount } \\
\text { Remaining Due to } \\
\text { Signaling }\end{array}$ \\
\hline $\mathrm{T}$ & $+5.885 \%$ & $+0.008 \%$ & $+5.893 \%$ & $+0.516 \%$ & $-5.377 \%$ \\
\hline $\mathrm{t}+1$ & $+5.885 \%$ & $+0.032 \%$ & $+5.917 \%$ & $+1.126 \%$ & $-4.791 \%$ \\
\hline $\mathrm{t}+5$ & $+5.885 \%$ & $+0.170 \%$ & $+6.055 \%$ & $+1.347 \%$ & $-4.708 \%$ \\
\hline $\mathrm{t}+30$ & $+5.885 \%$ & $+0.682 \%$ & $+6.567 \%$ & $+2.155 \%$ & $-4.412 \%$ \\
\hline $\mathrm{t}+60$ & $+5.885 \%$ & $+1.280 \%$ & $+7.165 \%$ & $+2.895 \%$ & $-4.270 \%$ \\
\hline $\mathrm{t}+365$ & $+5.885 \%$ & $+5.559 \%$ & $+11.444 \%$ & $+11.036 \%$ & $-0.408 \%$ \\
\hline
\end{tabular}

The amounts that could be attributed to the signaling theory were all negative, meaning that $M+I>P$, which produced a negative number for $S$, ranging from $-0.408 \%$ at $\mathrm{t}+365$ down to $-5.377 \%$ at $\mathrm{t}$. The results were more negative for $S$ the closer the date was to t. The farther away from t, the lesser was the negative number. But, the values for $S$ were always negative.

\section{Conclusions \& Implications}

- Conclusions

This study has resulted in the following conclusions, subject to the study limitations outlined in section 1.5 earlier in this paper.

1. The existence of abnormal returns for buyback stocks is supported, as found in numerous earlier studies.

2. The combination of the mathematical and the general market moves add up to more than the actual change in the buyback stock price.

3. No support is found for the signaling theory at either the theoretical $100 \%$ buyback level or the historical $80 \%$ buyback level.

\section{- Implications}

This researchpresents a conceptually yet empirically supported framework to describe the significance of the mathematical reduction in shares as a contributing factor in the post-buyback-announcement share price increase as compared to alternatives offered in the current literature. This paper is useful for those who study stock market behavior and the causes of the share price increase that follow a stock buyback announcement. In particular, this paper lends no quantitative support to the signaling theory, even though conceptually, the theory has qualitative merit.

\section{References}

Baker, H.K. (2009). Dividends and dividend policy. Hoboken, NJ: John Wiley \& Sons.

Baker, H.K., Powell, G.E., \&Veit, E.T. (2002). Revisiting the dividend puzzle: Do all the pieces now fit?

Review of Financial Economics, 11, 241-61. 
Brav, A., Graham, J.R., Harvey, C.R., \&Michaely, R. (2005).Payout policy in the 21st century. Journal of Financial Economics, 77, 483-527.

Brigham, E.F., \&Ehrhardt, M.C. (2014). Financial Management: Theory 7 practice, 14th ed. Mason OH: South-western Cengage.

Chetty, R., \&Saez, E. (2005). Dividend taxes and corporate behavior: Evidence from the 2003 tax cut. The Quarterly Journal of Economics, 120(3), 791-833.

DeAngelo, H., DeAngelo, L., \& Skinner, D.J. (2008).Corporate payout policy. Foundations and Trends in Finance, 3(2-3), 95-287.

Fama, E.F., \& French, K.R. (2001). Disappearing dividends: Changing firm characteristics or lower propensity to pay? Journal of Financial Economics, 60, 3-43.

Fruin, P., \& Ma, L. (2014). Buying outperformance: Do share repurchase announcements lead to higher returns? [White paper].Quantamental Research. Retrieved from http://www.spcapitaliq.com/ourthinking/resources-

ideas/Buying_Outperformance_Do_Share_Repurchase_Announcements_Lead_to_Higher_Re turns.pdf

Grullon, G., \&Ikenberry, D.L. (2000). What do we know about stock repurchases? Journal of Applied Corporate Finance, 13(1), 31-51.

Grullon, G., \&Michaely, R. (2002).Dividends, share repurchases, and the substitution hypothesis. The Journal of Finance, 57(4), 1649-1684.

Grullon, G., \&Michaely, R. (2004). The information content of share repurchase programs. The Journal of Finance, 59(2), 651-680.

Hsieh, J., \& Wang, Q. (2008).Insiders' tax preferences and firms' choices between dividends and share repurchases. Journal of Financial and Quantitative Analysis, 43(1), 213-244.

Ikenberry, D., Lakonishok, J., \&Vermaelen, T. (1995). Market underreaction to open market share repurchases. Journal of Financial Economics, 39, 181-208.

Lakonishok, J., \&Vermaelen, T. (1990). Anomalous price behavior around repurchase tender offers. The Journal of Finance, 45(2), 455-477.

Lease, R.C., John, K., Kalay, A., Lowenstein, U., \&Sarig, O.H. (2000). Dividend policy: Its impact of firm value. Boston: Harvard Business School Press.

Lightner, T. (2008).An analysis of dividend and capital gains tax rate differentials and their effect on the structure of corporate payouts.In S. Luttman (Ed.), Advances in taxation, 18, pp. 29-51. Bingley, UK: JAI Press.

Lightner, T.A., Morrow, M., Ricketts, R.C., \& Riley, M.E. (2008). Investor reaction to a reduction in the dividend tax rate: Evidence from the Jobs Growth Tax Relief Reconciliation Act of 2003. The Journal of American Taxation Association, 30(2), 21-46.

Peyer, U., \&Vermaelen, T. (2005). The many facets of privately negotiated share repurchases. Journal of Business Finance, 75(2), 361-395.

Peyer, U., \&Vermaelen, T. (2009). The nature and persistence of buyback anomalies. The Review of Financial Studies, 22(4), 1693-1745.

Ross, S.A., Westerfield, R.W., Jaffe, J.F., \& Jordan, B.D. (2011). Corporate finance: Core principles \& applications. New York: Mc-Graw-Hill Irwin.

Russolillo, S. (2016, March 17). Buybacks aren't what they used to be. Wall Street Journal, p. C-1.

S\&P Dow Jones Indices. (2017). S\&P 500®, Retrieved from http://us.spindices.com/indices/equity/sp500.

Stephens, C.P., \&Weisbach, M.S. (1998). Actual share reacquisition in open-market repurchase programs. The Journal of Finance, 53(1), 313-333.

Zeng, L. (2016). Examining share repurchasing and the S\&P buyback indices in the U.S. market.S\&P Dow Jones Indices.Retrieved from http://us.spindices.com/search/?query=zeng+april+2016+examining+share+repurchasing \&Se $\operatorname{arch}=\mathrm{GO} \&$ sortType $=$ Relevance $\&$ resultsPerPage $=25$. 
